Acta Universitatis Wratislaviensis • No 4046

Literatura i Kultura Popularna XXVI, Wrocław 2020

https://doi.org/10.19195/0867-7441.26.19

\title{
Maria Joana Melo
}

ORCID: 0000-0003-3168-5383

Institute for the Study of Literature and Tradition

(IELT-Nova FCSH), Nova University, Lisbon

\section{The heroic temper in Hamlet and Taxi Driver}

Keywords: Taxi Driver, Hamlet, neo-noir, heroic temper, Greek tragedy and cinema

Słowa kluczowe: Taksówkarz, Hamlet, neo-noir, heroizm, tragedia grecka i kino

A span of 400 years separates Travis Bickle from Hamlet. The circumstances of their stories and the realities they face are different. One is a prince, the other a nobody, and it is not possible to relate New York in the 1970s with a castle in Denmark, although this study aims at presenting Travis Bickle as a post-modern Hamlet. It is a near certainty that Scorsese did not have Hamlet in mind when he directed Taxi Driver, but the extraordinary resemblance between the two stories exceeds the design of the heroic temper, and it includes an almost symmetrical female dichotomy in Gertrude/Betsy and Iris/Ophelia.

Theatre is logographic and film is iconographic. In this study I will inevitably match words with images. Ophelia's purity is perceived in dialogue, Betsy's purity is perceived in a single frame with a white dress.

This study aims at understanding the heroic temper. A specific character design is presented as fertile ground for the appeal of drastic and violent action, sexual and creative frustration, in search of disruptive self-fulfillment, perceived as a heroic act. These characters are absolutely central and self-centered, and represent loneliness as well as bold individuality.

I have based my comparative study between Hamlet and Taxi Driver heavily on the essay Heroic Temper by Bernard Knox, built upon the examples of Sophocles. Both characters, Travis and Hamlet, seem to be fertile ground for psychoanalytical approaches to literature, especially Hamlet, who caught the attention of Freud and his followers. Taxi Driver has not been the object of academic research - apart from occasional film reviews - although its writer, Paul Schrader, men- 
tions several psychopathological issues regarding the film. In classical studies, the tragic hero is one who stands on the edge of an abyss, not looking down as he takes one step further. In Lacan's analytical work on Hamlet, such abyss is no longer the loss of identity, name, country, or status, but the loss of the phallus instead, a castration, which for Lacan is the main theme in Hamlet, and for me also very meaningful in Taxi Driver. However, the psychoanalytical speech follows some very specific premises, namely that the father/son relationship is one of lovehate, therefore neurotic, and that the child perceives the mother as one deprived of the phallus, as if women were not gifted with their own powerful protuberances. Without prejudice to the classical study of Bernard Knox, I have followed some psychological views presented by Lacan, applied to a literary work, because I assume that Shakespeare's and Scorsese's works come together by answering the same question: what is wrong with the kingdom of Denmark and the streets of New York? Sexuality. The neurotic association death/sex or love/hate starts in Hamlet's very first speech, connecting the sadness of the funeral with the joy of marriage. Throughout Taxi Driver we find connections of the same kind: while watching a porn film, Travis mimics a gun with his hand, and in the same scene we hear a voice over praising the size of a penis.

Conard in his The Philosophy of Film Noir classifies Taxi Driver as a neonoir, ${ }^{1}$ it complies to the noir aesthetic, it is dark and has voice-over narration, and plot: "The main character is lured into violence and usually to his own destruction, by the femme fatale". ${ }^{2}$ Finally, it also checks for noir themes: "bleak cynicism [...] social criticism, gangsters, private eyes and adventurers, middle-class murder, portraits and doubles, sexual pathology, and psychopaths, $[\ldots]$ loneliness and dread". ${ }^{3}$ Although this display of noir features can be applied to most popular fiction and entertainment, the most unique feature to noir is the pessimistic idea that we are all just food for maggots, "the quintessence of dust", as Hamlet says, or clay for the wall. In this regard both Hamlet and Taxi Driver move away from the classic model and come close to the crisis depicted in film noir, where man, life and love are "just something for the birds" as in Vincent Minnelli's The Bad and the Beautiful.

The psychological approach to Hamlet and Taxi Driver proved especially productive regarding Hamlet and Travis Bickle's relationships with women. The Scorsese character has been classified as an anti-hero. Hopefully this study will present such a character as deeply rooted in classic and shakespearean traditions that have designed the most heroic of heroes, the dark and intense tragic hero, who does not accept human limitations. ${ }^{4}$ In his own wretched way, Travis tries to bring

1 M.T. Conard, The Philosophy of Film Noir, Lexington 2006, p. 2.

2 M.T. Conard, "Nietzsche and the Meaning and Definition of Noir", [in:] The Philosophy of Film Noir..., p. 10.

3 Ibidem, p. 12.

4 B.M. Knox, The Heroic Temper. Studies in Sophoclean Tragedy, Berkley 1964, p. 17. 
his body to the superhuman level, he stresses his muscles, he ties and sticks guns to every accessible part of his body.

Another relevant issue for this comparative study between Hamlet and Taxi Driver is that both characters' minds are in a tormented state prior to the inciting incident. Travis's presentation in the first scene is that of someone who cannot sleep and has lost his way in life - due to post-traumatic stress disorder (PTSD) in Vietnam. ${ }^{5}$ Hamlet in turn is clearly distressed at his mother's marriage even before he is informed about the ghost. Both the play and the movie lead us through a psychological perception of events that might not spring from contingency, but from the characters' own tormented minds.

Some may object that there is an insurmountable difference between both works in that the status of the classic hero is always regal or grand, spoudaious, as Aristotle prescribed. A taxi driver could not equal the hero in greatness. I have argued before ${ }^{6}$ that genealogical contingency is not to be regarded as vital to the tragic ethos. The hero is someone who has the power of choice, proairesis, and the freedom to exercise his power over himself and others. If it were not so, women could not step up to the status of tragic character, which they do, in both Sophocles' and Euripides' works. The tragic hero must be someone who has much to lose, and in Travis' case that would be his life.

King or beggar, the tragic hero is full of self-importance. He believes he has a direct connection to God, or that his will is that of the people, or natural law, or nature, or the country. This is his hybris, his plural is majestic. The speech of the dictator is always confounding his will to that of the people, in a narcissistic act. L'état c'est moi is the same as "We are the People", which is Palantine's slogan acting as a leitmotif all throughout Taxi Driver. When running for election, an unspoken tyrant will give the idea that he heard a calling from God, the People, or the depths of his soul, alternatively even from his father's ghost. It is not without reason that Sophocles' tragedy is called Oedipus Tyranos, and not only Oedipus.

Most of the time, such appeal consist in cleaning the world of either adulterous women or pimps, scum, immigrants, or Jews. The messianic complex presents itself in the heroic ethos. Hamlet is consistently heroic when he says "This time is out of joint: O cursed spite, / that ever I was born to set it right!" (Act I, Sc. I). They all act for the greater good, claiming that the ends justify the means, thus opening the path for violence. Hamlet has no trouble assuming that he "must be cruel only to be kind / Thus bad begins and worse remains behind" (Act III, Sc. IV). The tyrant is presented as the one who will cleanse the world, be it from "faggots, junkies and whores", adulterous women and ambitious men, as in both

${ }^{5}$ M. Scorsese, I. Christie, Scorsese on Scorsese, New York 2004, p. 89.

6 M.J. Melo, Desígnio Inteligente - Actualização da Poética de Aristóteles como Teoria do Método e Funcionalidade Especificos de uma Arte Audiovisual de Larga Difusão, Universidade Nova de Lisboa, FCSH, Lisboa 2011, http://run.unl.pt/bitstream/10362/7985/1/DESIGNIO_INTE LIGENTE_TD.pdf (access: 21.04.2021). 
Taxi Driver and Hamlet, or Jews, immigrants or fascists, etc. Such a messianic complex is the core of the heroic ethos, opening the way to catastrophe, in the Aristotelian sense.

Narcissism accounts for their "messianic complex" (the concept does not exist in psychology) and provides absolution for their crimes, because it turns them into justified acts instead of murder, into a purge instead of genocide. Iago, in Othello, is the perfect anti-hero, for him murder is simply murder. Travis will save the streets of New York, Oedipus will save Thebes and Hamlet will save Denmark (which he will actually lose to Fortinbras). In Julius Caesar, Brutus says "we shall be called purgers, not murderers", and Othello says "she must die, else she'll betray more men", and the crimes are justified. Many times, by the end of the play, the hero is confronted with his crimes, finally recognizing them as meaningless bloodbaths and pride turns to shame.

Further similarities between both works come from the theme of suicide. In most American screenplay textbooks it is stated that the hero, or protagonist, should be taken to "the end of the line". ${ }^{7}$ Harold Bloom called it "the lust for ruin and its evolving intensity". ${ }^{8}$ When the death wish is driven to an extreme it often turns into a wish for damnation. "Roast me in sulfur", cries Othello," I am unworthy to go to hell", cries Oedipus. Both Hamlet and Travis feel utterly alienated from the world of men, and like the Sophoclean hero "turns his back on life itself and wishes, passionately for death [...] the hero chooses death", 9 which will become karis, a blessing.

Although Travis does not pretend to be mad like Hamlet (maybe because he really is going mad) he also enacts a role characterized in his new mohawk haircut that looks so opposite to his previous self. "Feigning madness is thus one of the dimensions of what we might call the strategy of the modern hero", ${ }^{10}$ and both Travis and Hamlet give us a forced, fictitious self. Travis has to become someone else to be able to kill, similarly to Hamlet needing to stage a murder, they are both an "artist of the self", as Harold Bloom states for Hamlet. ${ }^{11}$ The "To be or not to be" monologue encloses the idea of suicide, and Paul Schrader clearly stated that Taxi Driver is about a suicide pathology, most clear when Travis says to his colleague "I have some bad ideas in my mind". Both heroes dwell on suicide. When Travis goes out to kill the senator, he expects to die since he leaves a note for Iris, like Hamlet, who goes to the sword tournament knowing that something is wrong.

${ }^{7}$ R. McKee, Story: Substance, Structure, Style, and the Principles of Screenwriting, New York 1997, p. 319.

${ }^{8}$ H. Bloom on Shakespeare, Lecture for Shakespeare at Yale, https://youtu.be/4TzzWi5kPnA (access: 1.07.2021).

9 B.M. Knox, op. cit., p. 34.

10 J. Lacan, "Desire and the Interpretation of Desire in Hamlet", Literature and Psychoanalysis, The Question of Reading: Otherwise 1977, no. 55-56, p. 20.

11 Ibidem. 
There is, of course, the possibility that in dying they (or their author) expect atonement for the murder they wish to commit. In the shootout sequence Travis exhibits a serene and peaceful expression as he pretends to shoot himself. In Hamlet the same is expressed in words: "consummation devoutly to be wish'd".

The Greek word paranoia means excess thinking, just a step away from hallucination and eventually madness, not an uncommon feature among tragic heroes. Orestes, Othello, and Julius Caesar are epileptic, Macbeth suffers hallucination - and who knows if the old Hamlet ghost is real — as do Ajax and Hercules. Paranoia is the genesis of fiction, it can spring from fear of the dark, to give shape to that fear of the unknown is to write fiction, to be the creator of a fantasy. Distrust is the genesis of storytelling, which humans master so well. Crime fiction is therefore archetypical, be it Shakespeare, film noir, or the most uninteresting blockbuster. The rule of fiction is deception. The human fear of the wolf dressed as a lamb develops into the most sophisticated conspiracy theory, from which the word "plot" derives, creating the hustler, the con artist, the "Iagos" of the world. Mistrust and imagination make men "construe things after their fashion, clean from the purpose of things themselves", says Cicero in Julius Cesar.

Travis, his fellow driver says, thinks too much, and so does Hamlet. Ultimately, what is there to really think about but Death? Hamlet is not a man of action, he keeps fighting his contemplative nature, devoting his attention to Yorick, and drawing back when he is supposed to strike. The philosopher sits opposite the hero. Travis too is an observer. His eyes are shown in close-ups looking left and right, his slowly-moving car is reminiscent of a camera, and the mirrors in the car reflect his eyes in every direction, Scorsese virtuously frames his character's eyes.

Death is the meaningless meaning of everything. It is to be thought about, one's own death and that of others. These heroes fantasize about the killings, i.e., they fantasize about being a hero, taking "decisive action" as Travis puts it in his diary. Hamlet's and Travis's killing are delayed not only because they think too much about them but also because the fantasy alone seems to fulfill the act, until it does not. In Totem and Taboo one of Freud's neurotic patient "is inhibited in his ability to act, he regards the thought as replacement for action". ${ }^{12}$ Even when Hamlet cries: "O, from this time forth / My thoughts be bloody, or be nothing worth!" (Act IV, Sc. IV), he is still stuck to thoughts and not actions.

It is true that Freud's psychoanalysis is greatly inspired by literature - perhaps less by real life. In classic literature the key to the design of a tragic hero could be to kill the father, and whoever or whatever symbolizes him (the boss, the system, the law...). Adelman ${ }^{13}$ assumes that Hamlet is acting out the role of the father to build his own identity by taking on the qualities of the sold Hamlet. In Taxi Driver, the role of the father is first taken by the candidate Palantine (then by Sports, in

12 S. Freud, Totem and Taboo, trans. J. Strachey, London 2001, p. 224.

13 J. Adelman, Suffocating Mothers: Fantasies of Maternal Origin in Shakespeare's Plays, Hamlet to The Tempest, New York-London 1992, p. 12. 
the sense that he is a controller of women). When Travis meets Palantine in the car and asks him to "clean the city", he then assumes that mission himself. Again, in a word game note the resemblance of Palantine to "paladin", the noble knight devoted to rid the universe of evil, and then also "valentine": the lover. The old Hamlet is handsome:

\section{What a grace was seated on this brow? \\ Hyperion's curls; the front of Jove himself; \\ An eye like Mars, to threaten and command; \\ A station like the herald Mercury, \\ New-lighted on a heaven-kissing hill. (Act V, Sc. IV)}

Palantine is equally handsome. Betsy sells him as "intelligent, bold, and sexy" and this is the father that Hamlet and Travis want to be. In fact, as Aldeman states, how could Hamlet feel such visceral disgust at his mother's marriage if he did not assume his father's role? ${ }^{14}$ Travis runs to and away from Palantine: every time Betsy praises or explains Palantine, Travis draws the subject to himself. At the coffee shop, Betsy mentions the difficulties of organizing 50,000 volunteers, and Travis replies that he organizes himself, adding an unsuccessful joke.

Along with Betsy's devotion, the father spectrum, i.e. the posters of the candidate all over New York, give Palantine the coveted omnipotence of the father. Nobody rules over the father, nobody is worthier than him, nobody tells him what to do, so the two protagonists have a fierce sense of independence. As the Sophoclean hero, they will not admit being played. "Whilst thou play me, like an instrument?" is Hamlet's dreaded question to his friend Rosencrantz. Sadly, both Travis and Hamlet are played by fate. Hamlet is killed by a poisoned sword and Travis is spotted by a secret service man (better observer than him) before killing Palantine, then he also fails his own suicide by inadvertently running out of bullets. To be a hero is to rise above the common man - Hamlet says further in the play: "What is a man, if his chief good and market of his time be but sleep and feed? A beast no more [...]. I live to say this thing is to do", fully matching Travis' words: "I don't believe that one should devote his life to morbid self-attention".

In Hamlet the father is replaced by the uncle (as Palantine is replaced in Sport) whom Hamlet must kill to become himself someone: ecce homo, or as Travis says, "I am the man who did not take it anymore". He can only become the man after he kills Palantine. These fathers need to be killed, they are, as Lacan explains regarding Hamlet, "the handsome double" with whom "coexistence is impossible". 15 Why their actions to kill this ego ideal are aborted, I am not sure Hamlet misses the perfect moment to kill Claudius, and Travis fails to shoot Palantine but Lacan gives his plausible explanation: "he has entered into the game without, shall we say, his phallus", ${ }^{16}$ which could also explain why Travis is successful in killing Sport in

14 Ibidem, p. 13.

15 J. Lacan, op. cit., p. 32.

16 Ibidem. 
the shootout scene: he took his phallus with him, his "monster size" 44 Magnum. Quoting Freud, Lacan says Hamlet failed to kill Claudius because he cannot kill a signifier of power. ${ }^{17}$

Although a senator and a king are the loci of law and power, such power is felt both by Hamlet and Travis only through the control that the father exercises over women. Gertrude seems genuinely in love with Claudius, and Betsy truly admires Palantine, these women also serve their man's interests, Claudius needs Gertrude to legitimize his throne and Palantine needs Betsy to win the election. It is precisely around this point that Travis' and Hamlet's neuroses turn and to which all their attention is directed. In mainstream design secondary characters mimic the situation of the main character; in Hamlet Laertes and Fortinbras also come out to avenge their fathers. Polonius exercises the same male power and abuse over Ophelia, as does Sport over Iris, using her as a political tool. The killing of these father figures would therefore free these women. But it does not.Mainly because they do not wish to be saved, they consider themselves free, the perception of their situation as sinful, venal, or tragic occurs only in our heroes' minds. Even Iris has to be forced to perceive her situation as miserable.

One of the most recognizable features of the classic hero is his resoluteness: "He makes a decision which springs from the deepest layer of his individual nature, his physis (gut), and then blindly, ferociously, heroically maintains that decision even to the point of self-destruction". ${ }^{18}$ Outwardly, Travis seems more resolute than Hamlet, who is often taken as a paradigm for indecisiveness or hesitation, but throughout the film Travis' resoluteness seems forced, as he pops pills most avidly before the "decisive action". When Iris first comes to him for help, he does nothing and simply observes, immovable and silent, instead of driving off, saving her from her sordid world. He stares at Betsy before approaching her; he strangely stares Sport in the face, as if his look alone could kill him. Hamlet's tragic flaw is his inability to act, his dwelling on action and on his own willingness and unwillingness to act. ${ }^{19}$ Like Hamlet, Travis embodies opposite modes, the contemplative and the active, also because their target is much too diffuse, "the scum of the earth" is as vague as "a sea of troubles". Action becomes a chimera and assumes the proportions of salvation and self-fulfillment "My life has always been pointed in one direction, there never has been any choice for me. I see that now", says Travis. Similarly to Hamlet, he is a "human contradiction", in Betsy's words, balancing between self-glorification and self-loathing. In the very first scene Travis introduces himself at the taxi company desk looking and acting confidently, but when asked about "education", he becomes gloomy and ashamed. Following

17 Ibidem, p. 52.

18 B.M. Knox, op. cit., p. 7.

19 W. Kaufmann, Tragedy and Philosophy, Princeton 1968, p. 275. 
Robert Mckee's "end of the line", ${ }^{20}$ he will then go from misanthropy — "Man delights me not" (Hamlet) — to self-hatred.

In his study on the heroic temper, Bernard Knox does not leave out isolation. The history of the main character, protagonos, dates back to Sophocles. The centrality of his characters is not only scenic but also philosophical. Man and human action become the center of Greek tragedy after Aesquilus. The Sophoclean hero is forsaken, "he is monos, alone, eremos, abandoned, deserted [...] in his moments of deepest despair, he speaks neither to man nor to gods, but to the landscape". ${ }^{21} \mathrm{In}$ the DVD Extras, Paul Schrader says he chose a taxi driver because it is the loneliest of jobs, and Scorsese says he filmed Travis in a crowded atmosphere specifically to convey his loneliness. Travis does not speak to the landscape but to his diary and to a mirror. His famous words: "Are you talking to me? [...] I am the only one here" could have been Hamlet's words to the ghost. This loneliness also means that the tragic hero is not democratic or collective, he does not work for the whole. Travis is definitively not a team player and belongs nowhere, not even in the secret services or the police. Hybris in old Greek means not following rules, excess and marginality. For the audience of Athens, the cradle of democracy, such a capital hero must of course die. ${ }^{22}$

In both stories, although there is thorough planning and thinking, the final killings are neither planned nor clean. On the contrary, they seem to happen on the spur of the moment and the result is a bloody mess. Hamlet attacks his uncle in a moment of rage after being accidentally scratched by the poisoned end, and Gertrude dies by unknowingly drinking the poison meant for Hamlet. Travis freely shoots everyone he sees, and suddenly everybody shoots back at him. In the end, guns and swords have a life of their own. For Hamlet "an enterprise of great pitch and moment is sickeled o' her with the pale cast of thought" (Act III, Sc. I), so the hero must stop thinking when he is killing, giving way to arbitrary violence. To kill one guilty man, Hamlet kills six other innocents.

The neurotic need for purity directed at women is consistent with the aforementioned narcissism and hybris. The hero is unable to deal with a woman's free sexuality because it reminds him that he is a man like all others, bred by a carnal act of lust and chance, stripping him of the godliness he assumes. Like Hamlet Travis' world is also "sick and venal". The first sight of Betsy in a white dress brings Travis to say the words: "They/can/not/touch/her", longing for the unsoiled.

Disgust over feminine adultery is, as said before, a strong theme in both stories. In Taxi Driver the issue is highlighted in a sequence played by Scorsese himself, when he takes Travis's taxi to follow his adulterous wife and the dialogue between them is a gruesome reference to "what a 44 Magnum can do to a woman's vagina" at this point the neurotic association of death/sex, phallus/gun finds its

20 R. Mckee, op. cit., p. 215.

21 B.M. Knox, op. cit., p. 32.

22 Cf. Greek Tragedy and Political Theory, ed. J.P. Euben, Berkley 1986. 
way into the story. In turn, Hamlet's father seems more disgusted with his wife's adultery than with his own death: "to live / In the rank sweat of an enseamèd bed, / Love stewed in corruption, honeying and making / Over the nasty sty" (Act III, Sc. IV). Later in the film, alone in his room, Travis is watching a scene of female betrayal and adultery in a soap opera, when he then smashes the TV and holds his head as if he were in great pain.

There is a certain candidness in Travis' contradictory character, since he takes popcorn and soda to a porn movie. His first sexual approach is directed at the concierge of the porn theatre. Scorsese gives us a close-up of the table between him and the girl where we can read the words "sex life", which Travis does not have, in an opened magazine. The girl immediately discards him as a stalker and then "the disrespect and mockery of the world lock them even more securely in the prison of their passionate hearts, fill them with fierce resentment against those they regard as responsible for their sufferings". 23

Our neurotic heroes are stalkers; before cruelly pushing away Ophelia, Hamlet chases the young maid with love letters and gifts. In his famous essay on Hamlet, Lacan points out the precise moment in the play when Hamlet "kills" Ophelia, the object of his desire. ${ }^{24}$ Travis' object of desire, Betsy, is killed in that contradictory moment where he takes her on a first date to see a porn movie, "where he unconsciously soils her" - says Paul Schrader (DVD extras). After rejection, Hamlet and Travis both burst into anger and frustration; Hamlet calls Ophelia a "breeder of sinners" and tells her to go to a nunnery at least five times, among other insults (Act III, Sc. I). Travis tells Betsy "to die in hell" and from then on the mere mention of women will derange him. The mourning of both relationships is symbolized in flowers: the flowers surrounding Ophelia's madness and death, and the flowers meant for Betsy, filmed more than once rotting in Travis' small room. Gertrude and Betsy are worldly and self-assured, but Iris and Ophelia are played like instruments. They are both physically and socially dragged and pulled, and transmit speeches that are not their own. Iris' speech and ideas belong to slogans, to Sport, to astrology: "Sports says...", "He is a Libra", "haven't you heard of Women's Lib?".

The tragic plot is summarized by Horatio in Hamlet's final scene: "so shall you hear / Of carnal, bloody and unnatural acts; / Of accidental judgments, casual slaughters / Of deaths put by cunning and forced cause / And, in this upshot, purposes mistook / Fall'n on the inventors' heads: all this can I / Truly deliver" (Act V, Sc. II). In Murder Among Friends, Elizabeth Belfiore explains the tragic plot as a story of harm, murder or crime misdirected to someone in a relation of philia with the hero. In turn philia can include relatives, friends, supplicants and guests, but the

\footnotetext{
23 B.M. Knox, op. cit., p. 31.

24 J. Lacan, op. cit., p. 34.
} 
most tragic form of hurting a philos is to hurt oneself, "One's closest philos" ${ }^{25}$ Travis in this regard is more tragic than Hamlet, whose death is not heroic because it is passive. Note that in Greek tragedy suicide was not considered a noble way out, it could be the only way out of living in shame. Nevertheless, it should be the hero himself who acknowledges his helpless situation and puts an end to it. Now, there seem to be two endings in Taxi Driver: one downward tragic, but resolved by deus ex-machina, the other one upward and edifying. The first ending is the shootout. In his spree of violence, Travis kills not only Sport, but also the client who was with Iris and is a known public enemy mobster. This is what accidentally gives Travis the status of hero in the media. The tragedy would have been complete if when Travis tried to kill himself the deus ex-machina (or just luck) had not taken away his last bullet; Iris would then be left alone, abandoned in the middle of the horrific bloody mess, left as traumatized as Travis in his war days.

The second ending works as a eulogy for the hero. The paper clips on his wall are an epitaph to the man he became. Such an ending follows the upward formality of mainstream fiction. The final scene with Betsy in his car seems surreal, as if it has all been just a bad dream; Travis is strangely calm, he appears to have no desire, sexual, violent, or of any kind, as if he is dead or just a representation of himself, a mise en abîme in the rear-view mirror.

Travis Bickle is supposedly a man suffering from PTSD, with an increasing frustration and a desire to kill which feeds his hate as he drives along the most dangerous parts of the town. ${ }^{26}$ In this regard he has nothing to do with the young prince from Denmark. But I believe that stories and character designs spring from the need to deal with the emotions of fear and loss. Fiction provides many ways to purge these feelings just by representing them, this mimesis provides, according to Aristotle, ${ }^{27}$ the means to catharsis. What made me bring these two characters celebrated in our culture as icons, legos, key-rings, posters, t-shirts, etc. - together was not only their compliance with Knox's heroic temper, but also the idiosyncrasies that they share in their tormented ethic design prior to tragedy's mythos, and their rejection of the world as it is. In this study I have argued that the reasons why Hamlet and Travis became cult icons are very similar, and in the end they vanquished death like true heroes, in the sense that they are remembered to this day.

\section{Bibliography}

Adelman J., Suffocating Mothers: Fantasies of Maternal Origin in Shakespeare's Plays, Hamlet to The Tempest, Routledge, New York-London 1992.

Bloom H., Genius, Warner Books, New York 2002.

25 E. Belfiore, Murder Among Friends: Violation of Philia in Greek Tragedy, New York 2000, p. 101.

${ }^{26}$ M. Scorsese, I. Christie, op. cit., p. 90.

27 Cf. M.J. Melo, op. cit. 
Belfiore E., Murder Among Friends: Violation of Philia in Greek Tragedy, Oxford University Press, New York 2000.

Cacey M., "On Familiar Ground: Paul Schrader and the Death Impulse", Vagues Visages - International Film Criticism, https://vaguevisages.com/2018/05/21/on-familiar-ground-paul-schrader-and-the-death-impulse/.

Conard M.T., "Nietzsche and the Meaning and Definition of Noir", [in:] The Philosophy of Film Noir, ed. M.T. Conard, The University of Kentucky Press, Lexington 2006, pp. 7-22.

Dempsey M., "Taxi Driver by Martin Scorsese”, Film Quarterly 29, 1976, no. 4, pp. 37-41.

Freud S., Totem and Taboo, trans. J. Strachey, Routledge, London 2001.

Greek Tragedy and Political Theory, ed. J.P. Euben, University of California Press, Berkeley 1986. Interview with P. Schrader, https://www.avclub.com/paul-schrader-1798208245.

Kaufmann W., Tragedy and Philosophy, Princeton University Press, Princeton 1968.

Knox B.M., The Heroic Temper: Studies in Sophoclean Tragedy, University of California Press, Berkley 1964.

Lacan J., "Desire and the Interpretation of Desire in Hamlet", Literature and Psychoanalysis, The Question of Reading: Otherwise 1977, no. 55-56, pp. 11-52.

McKee R., Story: Substance, Structure, Style, and the Principles of Screenwriting, Harper Collins, New York 1997.

Melo M.J., Desígnio Inteligente - Actualização da Poética de Aristóteles como Teoria do Método e Funcionalidade Especificos de uma Arte Audiovisual de Larga Difusão, Universidade Nova de Lisboa, FCSH, Lisboa 2011, ttp://run.unl.pt/bitstream/10362/7985/1/DESIGNIO_INTELI GENTE_TD.pdf.

Melo M.J., "Ūm trágico final feliz”, Matlit 1, 2013, no 2, http://dx.doi.org/10.14195/2182-8830_12 -7.

Scorsese M., Christie I., Scorsese on Scorsese, Farrar, Straus and Giroux, New York 2004.

\section{Filmography}

Taxi Driver, dir. M. Scorsese, USA 1976.

\section{The heroic temper in Hamlet and Taxi Driver}

\section{Summary}

In this essay I wish to trace numerous affinities of theme, metaphor, and plot between Shakespeare's play Hamlet, Prince of Denmark and Martin Scorsese's film, Taxi Driver. Drawing from two claustrophobic settings, those of tragedy and film noir, the same anxiety, paranoia, and restlessness that contribute to the characterization of both heroes, Hamlet and Travis Bickle, as topoi of the Sophoclean tragic hero, conform to most features described by Bernard Knox in The Heroic Temper. 